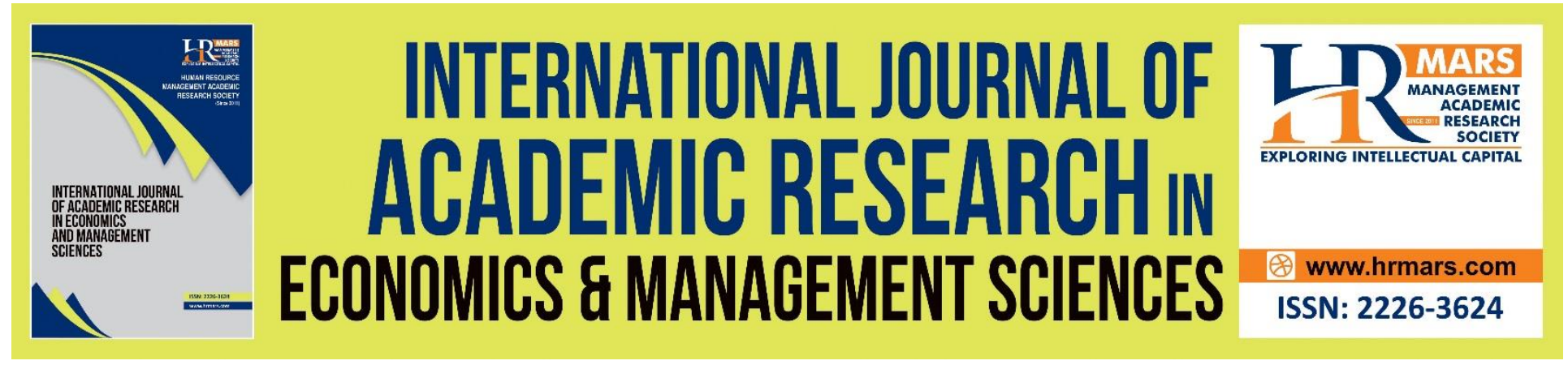

\title{
Discovering the Malaysian Consumers' Intention towards Green Purchase
}

Ima llyani binti Ibrahim, Mohd Fazly bin Mohd Razali, Zulaiha binti Ahmad, Zulkafli bin Mansor, Rozihanim binti Shekh Zain \& Normimi Esthakina binti Shah Riman

To Link this Article: http://dx.doi.org/10.6007/IJAREMS/v10-i3/10428

DOI:10.6007/IJAREMS/v10-i3/10428

Received: 11 April 2021, Revised: 10 May 2021, Accepted: 26 May 2021

Published Online: 09 July 2021

In-Text Citation: (Ibrahim et al., 2021)

To Cite this Article: Ibrahim, I. I. binti, Razali, M. F. bin M., Ahmad, Z. binti, Mansor, Z. bin, Zain, R. binti S., \& Riman, N. E. binti S. (2021). Discovering the Malaysian Consumers' Intention towards Green Purchase. International Journal of Academic Research in Economics and Managment and Sciences, 10(3), 63-74.

Copyright: (c) 2021 The Author(s)

Published by Human Resource Management Academic Research Society (www.hrmars.com)

This article is published under the Creative Commons Attribution (CC BY 4.0) license. Anyone may reproduce, distribute, translate and create derivative works of this article (for both commercial and non-commercial purposes), subject to full attribution to the original publication and authors. The full terms of this license may be seen

at: http://creativecommons.org/licences/by/4.0/legalcode

Vol. 10, No. 3, 2021, Pg. 63 - 74

http://hrmars.com/index.php/pages/detail/IJAREMS

JOURNAL HOMEPAGE

Full Terms \& Conditions of access and use can be found at http://hrmars.com/index.php/pages/detail/publication-ethics 


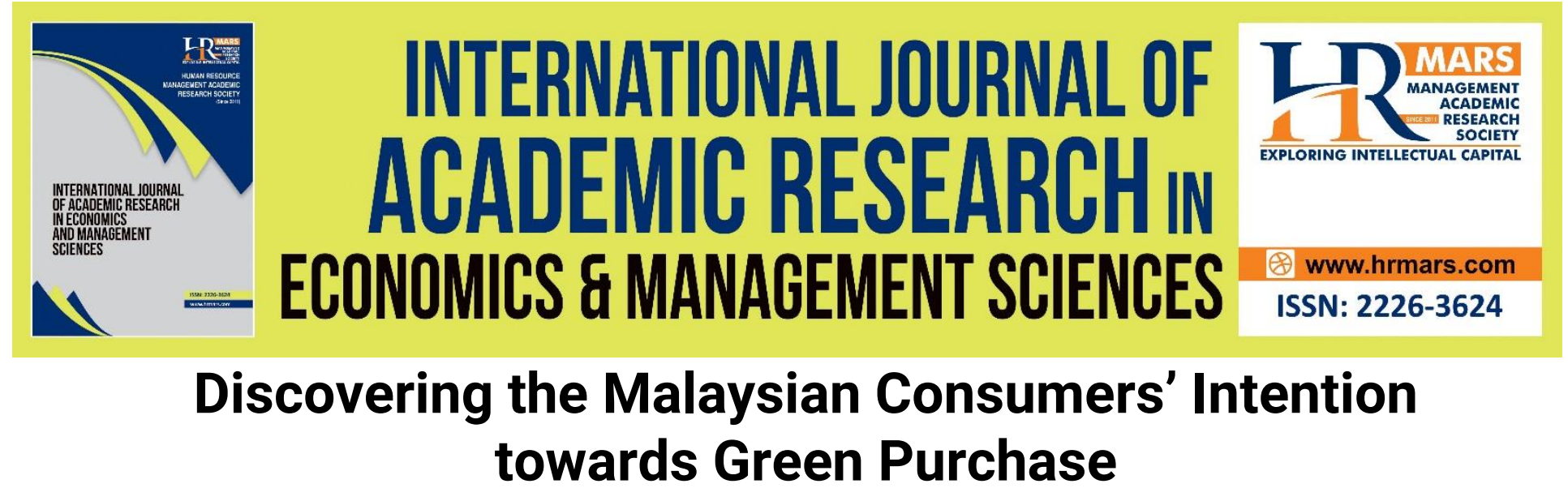

\title{
Ima Ilyani binti Ibrahim, Mohd Fazly bin Mohd Razali, Zulaiha binti Ahmad, Zulkafli bin Mansor, Rozihanim binti Shekh Zain \& Normimi Esthakina binti Shah Riman
}

Faculty of Business and Management, Universiti Teknologi MARA, Perlis Branch, Arau Campus, 02600 Arau, Perlis, Malaysia

Email: ilyani686@uitm.edu.my,mohdfazly@uitm.edu.my,zulaiha895@uitm.edu.my, zulkafli.masnor@uitm.edu.my,rozihanim@uitm.edu.my,mimieyesthakina@gmail.com

\begin{abstract}
The accelerated revolution of technology advancement and its application contributed towards changes in the environment and climate crisis. The healthy environment should be kept in the right mindset by the society in order to cater with the environmental issues. The climate changes, increased in air pollution, extreme whether condition and as well the higher number in the loss of animal and plant habitats are the signal of environmental degradation. Due to the increment of environmental awareness among Asian country, they had become the main target by international marketers to sells and promote on green products. Hence, the integration of Social Influence, Price, Environmental Attitude \& Concern, and Environmental Knowledge were used in predicting the Green Purchase Intention among Malaysian consumer. A total of 384 set of questionnaires have been distributed to consumers in Northern Malaysia using convenience sampling technique. The findings indicate there was a significant relationship among the studied variables. The study suggests that it is vital for the marketers to install and encourage a green purchase behavior among consumer to salvage the environment.
\end{abstract}

Keywords: Green Purchase Intention, Social Influence, Price, Environmental Attitude and Concern, Environmental Knowledge

\section{Introduction}

Over decades, the growth of the global economy along with the utilization of natural resources has led to environmental degradation. As study by Ramlogan (1997) stated that the climate changes around the world are the great picture that show it faces the great harassment by human. Therefore, the society starts to concern about the environmental issues that become worst day by day. Nowadays, consumers' concern toward the environmental issues becoming more important because they start to realize the purchase decision and behavior might affect the environment. Hence, the concept of green marketing had emerged in 1970s and green products become popular during 90s. As reported by Laroche et al (2001), consumers are becoming more gradually towards 
the environmental conscious, and now the green marketing concept become more substantial among them. Chan (2001) arbitrated that green marketing helps the companies to focuses more on the consumers that really care about the environment as they become potential customers that will purchase the green products. The green marketing campaign will become a platform of communication and will substantiate the relationship between environmental conscious firms and the consumers.

At present moment, most of the consumers claim that they understand the term "green" and purpose of green products. However, in reality they did not really comprehend the true idea and concept about the topic. The consumers only understood about the green product as a product that is environmental friendly which is not bringing harm to the earth. It demonstrates that consumer is only aware of the consequences caused by the usage of the product itself. A common perception of consumers towards the green products is that it has to be recycled.

Even the green marketing becomes a major trend in today's business world, but it is still new to Malaysia and other Asian countries (Wahid et al., 2011). In Malaysia, it was identified by Nik Abdul Rashid (2009), even the consumers have high knowledge on green products and eco-labels; they might not necessarily purchase the green products or services. To counter with the circumstances, the Malaysian government has taken on strong commitments towards protecting the environment. The initiative includes a marketing campaign aimed at raising public awareness of the importance of green practices. Together with the full support and resolutions of the government (Draskovic et al., 2009), the Malaysian business community has launched a broad campaign to promote an environmentally friendly lifestyle. Latterly, a few companies such as Body Shop, Aeon Co (M) Bhd, Canon Malaysia, and Sime Darby has resolute on green initiatives programs such as "No Plastics Bag Campaign Day", "Return and Recycle", "Plant a Tree Program" and other few programs that lead to sustainable and useful in helping the world go green and healthy.

Although there are many environmental friendly products that have been introduced in the market, but still the consumer endeavors to their old buying habits and would not lured the action convert to green products as their preferences. Only a few customers would dictates on the environmental concerns and exhibit it through the actual purchase behavior (Grunert, 1993). This clearly shows that even though many people aware about the environment issues and environmental friendly products and services but the diffusion of action would still very slow. The phenomenon was supported by the surveyed by Our Green World (2008), they found that only $8 \%$ of the respondents that changed their purchasing behavior to assist the environment. This explains that consumers' reaction to green products is not consistent. The same finding by Alwitt \& Bergers's as cited in YamTang and Chan (1998), found the consumers did not carry the green manner although they aware on the breakdown of environment since they are not buying the green products or services even though they said the care on environment.

Along comparatively, most of the consumers do not want to abandon the product functions for ethics and price often matters to them. This is ascribed to the huge price differences that influence consumer purchase decision. The price of green products tends to be higher than conventional products that offer similar functions and purpose. The findings from countless studies that have been carried out by previous researcher regarding the green purchase intention were against each other and it may occur due to the research outcome are may be only relevant in certain period, geographical or demographical cause of shifting in consumers purchase intentions towards green products. Thus, because of the difficulties in understanding the consumer behavior towards 
purchasing the green product, the purpose or objective of the study was initiated to identify whether social influence, price, environmental attitude \& concern and environmental knowledge provide the positive or adverse impacts to the purchase intention of green products among Malaysian. This study attempts to provide benefits to the companies by contributing knowledge to consumers regarding green products and lead them to practicing green purchase behavior.

\section{Literature Review}

\section{Green Purchase Intention}

Green purchase intention can be manifested as the readiness of the customer in the decision making process to choose and use the green products compared to the conventional products in the current market (Aman et al., 2012; Rashid, 2009; Ali \& Ahmad, 2012). As attested by Beckford et al (2010); Chan (2001), green purchase intention is an important factor of the green purchase behavior and it means that purchase intention will be positively affecting the customer decisions whether he will purchase the green products or not. In supplementary, Lee (2008) explained that the green purchase intention is one of the way for the consumers to choose the products or services that give slightest destructive to the environment and human health.

Another study Park \& Ha (2012) confirmed that the green purchase intention can be a point of references for the future behavior in response to the purchase of green products. Meanwhile, Albakyrak et al (2013) mentioned the green purchase intention as an important factor in order to determine the real or actual buying behavior of an individual based on the Theory of Planned Behavior. Thusly, to increase the intention of green purchasing, the consumer awareness should be highlight at the first place. In creating and enhancing greater awareness to the consumers, many companies may be involved in programs that promote the environmental friendly products. As studied by Lalit \& Kanokthip (1998), media can play an important role in creating and enhancing awareness by educating the consumers about the essential benefits of environment conservation to the society.

\section{Social Influence}

The social influence is usually the changes of a person's attitude and behavior that will be influenced by another person's action (DeLamater and Myers, 2010). The person usually gains the knowledge about green products from his or her family, discuss about the environmental products with their friends and usually will share the information with the family members (Finisterrado Paco \& Raposo, 2004). In accordance with Maram \& Kongsompong (2007), social influence consists of friends, family, and also strangers.

Baker and Ozaki (2008) in their study shows social influence are important in driving ecologically accountable behavior. Instead, they declare that social norm has a powerful link to environmental friendly behavior which it capable of pressure the people shopping for the green products. In Malaysia, a studied by Nabsiah et al (2011) conclude that the social influence is discovered to be the best predictor of green purchase behavior since it has an immediate and substantial effect on intention. This finding were supported by previous studies by Mangleburg, Doney \& Bristol (2004); De Leon \& Fuqua (1995); Schults (1999) that the impact of social influences on our behaviors may be at an extra conscious degree. In particular, individuals use less heating fuel and recycle if they are informed of family and neighbors. Therefore, the attitude of caring for the 
environment should be practiced starting from an early age since children might affected with their peers' ideals and behaviors in the improvement stage, especially in young adolescent stages.

\section{Price}

Consumers are usually intrigued by price when they want to going green (D'Souza et al., 2006). Young et al. (2010) identified price as an obstacle to Green Purchase Behavior because it will weaken the impact of green values and attributes in forming purchase decision. Regularly the consumers who are involved with the nature are willing to pay a premium price to purchase the green products compared to those who are less involved with the nature (Vlosky, Ozanne \& Fontenot, 1999). Price is an extrinsic cue that can be the deciding factor when consumer has to choose in the whole evaluation process of the product.

In general, the price for the green product will be higher than the conventional products due to the higher cost incurred in the process, materials and certain cost that involved in manufacturing the products. Price will always be as the determinant factor in making purchase decision. In conformity with Barnard and Mitra (2010), the consumers usually willing to pay for a premium price on the green product that had certification compared to the one that self-declared by the company itself. As the survey conducted by J. Walter Thompson, an advertising agency, there were $82 \%$ of the respondents said they would pay at least $5 \%$ more for a product that is environmental friendly (D'Sauza, 2005).

\section{Environmental Attitude and Concern}

Nik Abdul Rashid (2009) defined environmental attitude as a learned tendency to react regularly to appropriate or inappropriate attitude regarding to the environment. Environment attitude usually would influence consumers' attitude and buying decisions (Schwepker and Cornwell, 1991). Environmental attitude also has been defined as a set of trust, impact and behavioral intentions a customer keep regarding environmentally linked events or outcome. The environmental attitudes can be categorized in three types which are altruistic, self-centered attitudes, and ecocentric attitudes. Altruistic attitudes include the concerns over others; self-centered attitudes include their responsibility, whereby eco-centric attitudes include care for the environment (Schultz et al., 2000).

Accordant with Chan and Lau (2000), environmental concern has difference explanation which depend on viewpoint and its mess up and inconstant nature. However, the early definition of environmental concern was the degree of preventive approach towards environment (Crosby, Taylor \& Gill, 1981), but later was defined as a general attitude which has an indirect effect on attitude though behavioral objective (Gill, Crosby \& Taylor, 1986). Therefore, environmental concern can be presumed that a customer was emotionally involved to environmental related issues.

\section{Environmental Knowledge}

Knowledge is illustrated as the amount held in the memory that people held which is consists on information in which influences consumers to evaluate and figure out the accessible options (Blackwell et al., 2001). However, environmental knowledge in this study refers to the consumer's knowledge on environmental issues, including the environmental conditions in Malaysia and how consumers utilize this knowledge to conserve the environment. Rokicha (2002) found that the achievement of a high point of environmental knowledge lead to more suitable pro-environmental 
behavior. In addition to that, Mostafa (2009) found that environmental knowledge has a meaningful influence on the consumers' intention to purchase Green Product. Previous studies conducted by Schahn and Holzer (1990) issued two forms of environmental knowledge, namely "abstract" (regarding environmental effects, elements, difficulties, results) and "concrete behavioral knowledge" (factual knowledge).

Throughout the studies, abstract environment knowledge can be seen to be more likely influence the environmental actions compared to the factual knowledge. In agreement with Chan (2001); Haron et al (2005), environmental knowledge refer to individual's capability to acknowledge the environmental effects, analyze, and more considerate effect of the ecosystem on the entire society. Noor et al. (2012) exhibited that environmental knowledge has led to consequences on environmental attitude in Malaysia. The lack of knowledge was a main barrier to recycle among the people with positive attitudes (Simmons and Widmar, 1990).

\section{Research Framework}

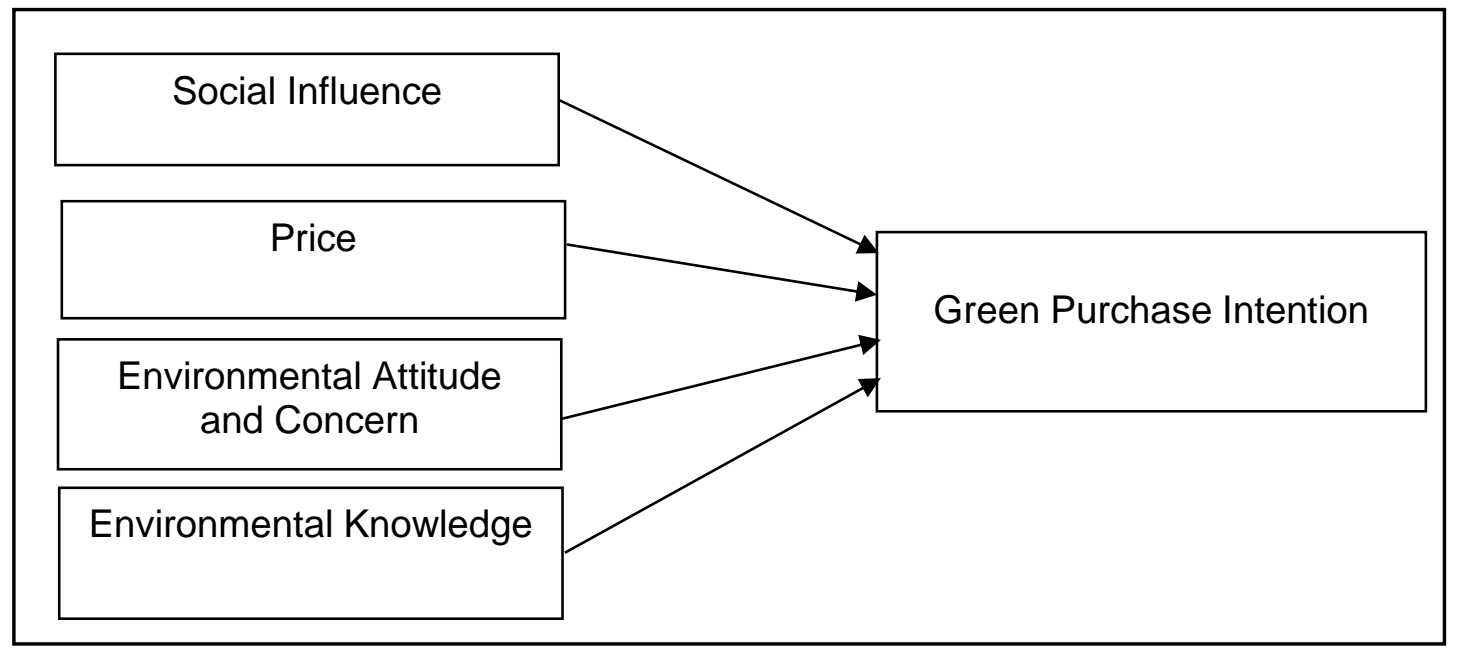

Figure 1 Theoretical Framework

Sources: Lasuin, \& Ching (2014); Anvar (2014)

\section{Methodology}

This study focused on the consumers that were selected from Northern Region of Malaysia using mall-intercept technique. Since this study was done before the Covid-19 pandemic, a number of 384 respondents were accessible at numerous hypermarkets, shopping malls and supermarkets located in Perlis, Kedah, Penang and Perak. The process involved identifying the prospects, approached them and administering a survey on the spot. The convenience sampling techniques assists the researcher to choose the right target sample as respondents were available to be interviewed and willing to participate at the moment of consecutively the survey. The questionnaire encompasses of two languages which in Malay and English to accommodate respondent's preference. It consists of five sections with 31 items that adopted from previous scholars including respondents' demographic. To measure the items, Likert scale of 1 to 5 (from the lowest value of 1 indicate to "strongly disagree" and the largest 
INTERNATIONAL JOURNAL OF ACADEMIC RESEARCH ECONOMICS AND MANAGEMENT SCIENCES

Vol. 10, No. 3, 2021, E-ISSN: 2226-3624 ㄷ 2021 HRMARS

value of 5 indicate to "strongly agree") were used to collect information. The instruments used for this study were adapted from various sources presented in Table 1.

Table 1 The Sources for Questionnaires for Each Variables

\begin{tabular}{llc}
\hline Variables & \multicolumn{1}{c}{ Source } & No. of Item \\
\hline Green Purchase Intention & Kabadayi et al. (2015), Maichum et & 7 \\
& al. (2017) & \\
Social Influence & Mei et al. (2012) \& Li et al. (2007) & 5 \\
Price & Silva et al. (2015) \& Maichum et al. & 4 \\
& (2017) & \\
Environmental Attitude and Concern & Maichum et al. (2017), Silva et al. & 5 \\
& (2015) \& Mei et al. (2012) \\
Environmental Knowledge & Lee (2017) \& Maichum et al. (2017) & 5 \\
\hline
\end{tabular}

\section{Findings Analysis}

The summary of descriptive analysis such as mean, minimum; maximum and standard deviation that obtained from all variables were provided in Table 2. All variables were taped on a five-point scale. The means for all study variables are between 3.6234 and 3.9542, indicating that majority of the respondents nearly agreed that the four indicators have a significant effect towards green purchasing. The values of standard deviation indicates the ranged from 0.52 until 0.59 .

Table 2 Descriptive Analysis

\begin{tabular}{lcccc}
\hline \multicolumn{1}{c}{ Variables } & Minimum & Maximum & Mean & Std. Deviation \\
\hline Social Influence & 1.00 & 5.00 & 3.6234 & .59 \\
Price & 1.00 & 5.00 & 3.7031 & .52 \\
Environmental Attitude and & 1.00 & 5.00 & 3.9542 & .52 \\
Concern & & & & \\
Environmental Knowledge & 1.00 & 5.00 & 3.8484 & .57 \\
\hline
\end{tabular}

Table 3 represents the result of reliability analysis. A value that is close to 1 indicates high reliability. As can be seen, Cronbach's Alpha for all variables is above 0.70 that remarks as good; only one variable consider acceptable with the Cronbach's Alpha value is 0.532 . Thus, it indicates that all items measure is approximately acceptable and reliable.

Table 3 The Reliability Analysis

\begin{tabular}{ccc}
\hline Variables & No. of items & Cronbach's Alpha \\
\hline Green Purchase Intention & 7 & .839 \\
\hline
\end{tabular}




\begin{tabular}{lll}
\hline Social Influence & 5 & .781 \\
Price & 4 & .532 \\
Environmental Attitude and & 5 & .719 \\
Concern & & .829 \\
Environmental Knowledge & 5 & \\
\hline
\end{tabular}

Pearson Correlation Analysis was explained in Table 4. The correlational analyses among the variables indicate that social influence $(r=0.462, p=0.00)$, environmental attitude and concern $(r=0.552, p=0.00)$ and environmental knowledge $(r=0.480, p=0.04)$ are correlated with transfer of training. Meanwhile, for price $(r=0.460, p=0.028)$ is not correlated with the dependent variable. Thus the results of correlation analysis provide initial support for the study hypotheses. All the independent variables have moderate relationship towards the dependents since the $r$ value are between 0.46-0.55.

Table 4 Correlation Analysis

\begin{tabular}{lccccc}
\multicolumn{1}{c}{ Variables } & SI & P & EAC & EK & SIG \\
\hline Social Influence & 1 & & & & .000 \\
Price & $.513^{* *}$ & 1 & & & .028 \\
Environmental Attitude and Concern & $.385^{* *}$ & $.532^{* *}$ & 1 & & .000 \\
Environmental Knowledge & $.339^{* *}$ & $.432^{* *}$ & $.658^{* *}$ & 1 & .004 \\
Green Purchase Intention (DV) & $.462^{* *}$ & .460 & $.552^{*}$ & $.480^{* *}$ & \\
\hline
\end{tabular}

In Table 5, the result of multiple regressions is presented. The whole model explained $39.4 \%$ of the variance in green purchase intention. All of four independent variables which are social influence, price, environmental attitude \& concern and environmental knowledge significantly predicted green purchase intention with $(\beta=.205, p>0.1),(\beta=.111, p>0.1),(\beta=.296, p>0.1)$ and $(\beta=.138, p>0.1)$ respectively. Hence, all the study hypotheses were accepted

Table 5 Multiple Regression Analysis

\begin{tabular}{lcl}
\hline \multicolumn{1}{c}{ Variables } & $\beta$ & Sig. \\
\hline Social Influence & .205 & .000 \\
Price & .111 & .028 \\
Environmental Attitude and Concern & .296 & .000 \\
Environmental Knowledge & .138 & .004 \\
Adjusted R Square & .394 & \\
\hline
\end{tabular}

\section{Discussions}

The results of the findings indicate that social influence, price, environmental attitude and concern and environmental knowledge had become the mechanisms that assist customer's intention towards green purchasing. The study found that all variables have significant and positive relationship with the green purchase intention among Malaysian consumer. The upsurge in environmental education leads to enhanced awareness especially among young generation where the schools can give an attention and considered the activities on environmental education be cover within the education system and the lack of understanding can be eradicate. 
The environmental education may be included in the syllabus in order to make sure the adolescents are well educated. This is supported by Coddington (1993) that states the environmental marketing is the seeds of environmental education. If the consumers were being taught when they were small, it not only can motivate them to be more concern towards environment, but also becoming green consumers in the future.

In an effort for the consumer to purchase the green products, the marketer may use multiple medium to widen the benefits or extend knowledge among them. Therefore, the usage of online social network such as Facebook, TikTok, Instagram and Twitter for advertising and promoting green or environment friendly products may become the best tools to get closely connected with people. As founded by Jupiter Research (2007), social network users were three times are likely trust peer's opinions over advertising when making purchase decision. The social network would be a part to gain publicity because the user review on green products and environmental issues can attract their attention and could increase the environment attitude and concern among the uses of social network.

This study also inaugurate that the different in price interferes in the intention to buying green product. At the present time, price still remain the main barrier towards green products purchase decision. Consumers in general will purchase products and services with a mix of attributes including the environmental attributes, but not all consumers are willing to pay a higher price for the green products. The consumers usually did not found appropriate functional options among the current selection of eco-friendly products in the market. A lower price caused by cost saving will encourage consumers to buy environmental friendly products. When the demand for a product is a price sensitive, the lower pricing strategy will be successful implementation towards the green products. This is supported by Young, Hwang, McDonald \& Oates (2010) that price are one of the influencing factors in the green purchasing process.

\section{Conclusions}

The current study has concluded that there is a significant relationship between all independent variables with the green purchase intention among consumers in Malaysia. Even many people may have ecological concerns, but most of them feel that environmental protection is the responsibility of the government or huge corporation. That is the current status quo in Malaysia. Therefore, protecting the environment should become the responsibility of everyone who lives in this world, and to create green purchase behavior among individuals, the people's perceived responsibility should be felt in daily practices. Hence, this indicates that future study and action on this area is still much needed to make sure the green lifestyle practices could be executed in Malaysia and as well globally.

The contribution of this study is quite significant to the development of green marketing structure and strategies which is still new in Malaysian context. Green marketing concept promotes to establish the link between business practices and the role of social responsibility (CSR) among the firms for realizing the healthy environment. The effective of green marketing framework would lead to achieving customer loyalty. Thus, it will enhance the positive image of the company in the eyes of the consumer. The green purchase intention and behavior can be diffused effectively not only by the intervention of government, but the role of social responsibility (CSR) practices among the firms in Malaysia. Strategic green marketing orientation will become essential tools for the top level management to develop action and policies in 
INTERNATIONAL JOURNAL OF ACADEMIC RESEARCH ECONOMICS AND MANAGEMENT SCIENCES

Vol. 10, No. 3, 2021, E-ISSN: 2226-3624 ㄷ 2021 HRMARS

nurturing green products. A compatible green marketing strategy will serve as the platform to educate and to promote the consumer in green purchasing intention behavior action.

\section{Acknowledgement}

Thank you to all respondents for their involvement during the collection of data that contribute to fruitful in producing the script.

\section{References}

Ali, A., \& Ahmad, I. (2012). Environmental friendly products: factors that influence the green purchase intentions of Pakistani consumers. PJETS, 2 (1), 84-117.

Aman, A. L. (2012). The influence of environmental knowledge and concern on green purchase intention the role of attitude as a mediating varibale. British Journal of Arts and Social Sciences. Vol. 7(3), pp 2046-9578.

Anvar, M., and Venter, M. (2014). Attitudes and Purchase Behavior of Green Products among Generation Y Consumers in South Africa, Medditerranean Journal of Social Sciences (online), 5(21), pp. 183-194. Available at:

http://www.mcser.org/journal/index.php/mjss/article/viewFile/4101

Barnard, E., \& Mitra, A. (2010). A contingent valuation method to measure willingness to pay for eco-label products. Allied Academies International Conference: Proceedings of the Academy for Economics \& Economic Education (AEEE), 13(2), 5-10.

Beckford, C. L., Jacobs, C., Williams, N., \& Nahdee, R. (2010). Aboriginal Environmental Wisdom, Stewardship, and Sustainability: Lessons from the Walpole Island First Nations, Ontario, Canada. The Journal of Environmental Education, 41(4), 239-248.

Blackwell, R. D., Miniard, P. W., Engel, F. J. (2001), Consumer Behaviour. Orlando: Harcourt College Publishers.

Chan, R. Y. K. (2001). Determinants of Chinese consumers' green purchase behavior. Psychology and Marketing, 18 (4), 389-413. http://dx.doi.org/10.1002/mar.1013

Coddington, W. (1993). Environmental Marketing's New Relationship with Corporate Environmental Management. Environmental Quality Management, 2, 297-302. http://dx.doi.org/10.1002/tqem.3310020310

Crosby, L. A., Gill, J. D., and Taylor, J. R. (1981). Consumer voter behaviour in the passage of the Michigan Container Law. Journal of Marketing. Iss. 45, pp. 349-354.

DeLamater, J. D., \& Myers, D. J. (2010). Social psychology. United States: Cengage Learning

DeLeon, I. G., \& Fuqua, R. W. (1995). The effects of public commitment and group feedback on curbside recycling. Environment and Behavior, 27(2), 233-250. https://doi.org/10.1177/0013916595272007

D'Souza, C., Taghian, M., and Lamb, P. (2005). Public environmental consumerism: Recycling behavior and its impact on intentions to purchase green products. Paper presented at Proceedings of the 30th Annual Macromarketing Conference, St. Petersburg, Florida, USA. 28-31 May.

Finisterra do Paço, A. M., \& Raposo, M. L. B. (2010). Green consumer market segmentation: empirical findings from Portugal. International Journal of Consumer Studies, 34(4), 429-436.

Gill, J. D., Crosby, L. A., \& Taylor, J. R. (1986). Ecological concern, attitudes, and social norms in voting behavior. Public Opinion Quarterly, 50(4), 537-554. https://doi.org/10.1086/269002 
Grunert, S., (1993). Everyone seems concerned about the environment but is thos concern reflected in Danish consumers' food choice? European Advances in Consumer Research, Issues 1, pp. 428-433.

Haron, S. A., Paim, L., and Yahaya, N. (2005). Towards Sustainable Consumption: An Examination of Environmental Knowledge among Malaysians, International Journal of Consumers Studies, 29(5), 426-436.

Kabadayı, E. T., Dursun, I., Alan, A. K., \& Tuğer, A. T. (2015). Green Purchase Intention of Young Turkish Consumers: Effects of Consumer's Guilt, Self-monitoring and Perceived Consumer Effectiveness. Procedia -Social and Behavioral Sciences, 207, 165-174. https://doi.org/10.1016/j.sbspro.2015.10.167

Lalit, M. J., and Kanokthip, S. (1998). Green marketing of cosmetics and toiletries in Thailand. Journal of Consumer Marketing, 15(3), 265 - 281.

Laroche, M., Bergeron, J., \& Barbaro-Forleo, G. (2001). Targeting consumers who are willing to pay more for environmentally friendly products. Journal of Consumer Marketing, 18, 503520. http://dx.doi.org/10.1108/EUM0000000006155

Lasuin, C. A., \& Ching, N. Y. (2014). Factors influencing green purchase intention among university students. Malaysian Journal of Business and Economics, 1(2), 1-14.

Lee, K. (2008), "Opportunities for green marketing: young consumers" Marketing Intelligence \& Planning, 26, 53-586. http://dx.doi.org/10.1108/02634500810902839

Lee, Y. K. (2017). A comparative study of green purchase intention between Korean and Chinese consumers: the moderating role of collectivism. Sustainablity 9:1930. doi: $10.3390 /$ su9101930

Li, J. J., \& Su, C. (2007). How face influences consumption-A comparative study of American and Chinese consumers. International Journal of Market Research, 49(2).

Maichum, K., Parichatnon, S., \& Peng, K. C. (2017). Developing an extended Theory of Planned Behavior Model to investigate consumers' consumption behavior toward organic food: a case study in Thailand. International Journal of Scientific \& Technology Research, 6(1), 7280.

Mangleburg, T. F., Doney, P. M., Bristol, T. (2004). "Shopping with Friends and Teens Susceptibility to Peer Influence," J. Retailing. 80: 101-116

Maram, H. K., \& Kongsompong, K. (2007). The power of social influence: East-West comparison on purchasing behavior. International Marketing Conference on Marketing \& Society, $649-$ 655.

Mei, O. J., Ling, K. C., \& Piew, T. H. (2012). The Antecedents of Green Purchase Intention among Malaysian Consumers. Asian Social Science, 8 (13), 248-263.

Mostafa, M. (2009). Shades of green: A psychographic segmentation of the green consumer in Kuwait using self-organizing maps. Expert Systems with Applications, 36(8), pp. 1103011038.

Abdul Rashid, N. R. (2009). Employee involvement in EMS/ISO 14001 and its spillover

Noor, N. A. M., Muhammad, A., Kassim, A., Jamil, C. Z. M., Mat, N., Mat, N., \& Salleh, H. S. (2012). Creating green consumers: how environmental knowledge and environmental attitude lead to green purchase behavior? International Journal of Arts \& Sciences, 5 (1), 55-71.

Park, J., \& Ha, S. (2012). Understanding pro-environmental behavior: A comparison of 
Pickett-Baker, J., Ozaki, R. (2008). Pro-environmental products: marketing influenceon consumer purchase decision. The Journal of Consumer Marketing. 25 (5), 281.

Ramlogan, R. (1997). Environment and human health: a threat to all. Environmental Management and Heath, 8(2): 51-66.

Rashid, N. R. N. A. (2009). Awareness of eco-label in Malaysia's green marketing initiative. International Journal of Business and Management, 4(8), 132-141. http:dx.doi.org/10.5539/ijbm.v4n8p132

Rokicka, E. (2002). Attitudes towards natural environment. International Journal of Sociology, 32(2), pp. 78-90.

Schahn, J., \& Holzer, E. (1990). Studies of Individual Environmental Concern The Role of Knowledge, Gender, and Background Variables. Environment and Behavior, 22(6), 767-786. http://dx.doi.org/10.1177/0013916590226003

Schultz, P. W. (2000). Assessing the structure of environmental concern: Concern for self, other people, and the biosphere. Unpublished manuscript.

Schultz, P. W. (1999). Changing Behavior with Normative Feedback Interventions: A Field Experiment on Curbside Recycling. Basic and Applied Social Psychology, 21, 25-36. http://dx.doi.org/10.1207/s15324834basp2101_3

Schwepker, C. H., and Cornwell, R. B. (1991). An examination of ecologically concerned consumers and their intention to purchase ecologically packaged products. Journal of Public Policy and Marketing, 10(2), pp. 77-101.

Silva, S., Junior, B., Luiz, M., \& Gabriel, D. S. (2015). The Effects of Environmental Concern on Purchase of Green Products in Retail. Procedia - Social and Behavioral Sciences, 170, 99108. https://doi.org/10.1016/j.sbspro.2015.01.019

Simmons, D., and Widmar, R. (1990). Motivations and barriers to recycling: Toward a strategy for public education. Journal of Environmental Education, 22(1), pp. 13-18. sustainable consumers and apathetic consumers. International Journal of Retail \&

Vlosky, R., Ozanne, L., and Fontenot, R. (1999). A conceptual model of US consumer willingness to pay for environmental certified wood products. Journal of Consumer Marketing, 16(2): 122-140.

Wahid, N. A., Rahbar, E., \& Tan, S. S. (2011). Factors influencing green purchase behavior of Penang environmental volunteers. International Business Management, 5(1), 38-49. http://dx.doi.org/10.3923/ibm.2011.38.49

Yam-Tang, E. P. Y., \& Chan, R. Y. K. (1998). Purchasing behaviors and perceptions of environmentally harmful products. Marketing Intelligence and Planning, 16, 356-362.

Young, W., Hwang, K., McDonald, S., \& Oates, C. J. (2010). Sustainable consumption: green consumer behaviour when purchasing products. Sustainable Development, 18(1), 20-31. 